\title{
Boca do Amazonas: roman-fleuve e dictio-narium caboclo em Dalcídio Jurandir
}

\author{
Willi Bolle \\ Universidade de São Paulo. São Paulo, São Paulo, Brasil
}

\section{INTRODUÇÃO}

O estudo que Benedito Nunes publicou em 2006, com o título "Dalcídio Jurandir: as oscilações de um ciclo romanesco" (Nunes, 2006), traz em apenas sete páginas uma instigante visão de conjunto da obra do grande romancista paraense. Para o autor do presente artigo, que proferiu, em 2010, conferência sobre uma das obras-chave de Dalcídio, a releitura do estudo do crítico belenense foi um estímulo importante para retomar o texto daquela palestra. O que aqui se apresenta é o resultado de uma fusão daquela redação provisória e de um comentário das ideias e observações de Benedito Nunes.

A conferência focalizava os procedimentos poéticos de pesquisa da cultura amazônica, em "Ribanceira" (Jurandir, 1978), o último dos dez romances publicados por Dalcídio a partir de 1941 e que constituem o seu Ciclo do Extremo Norte. A partir de uma comparação dessa obra de ficção com pesquisas antropológicas (Humboldt e Wagley), foi realçada como principal característica diferenciadora do romance o projeto de organizar um 'dicionário' da cultura amazônica, no sentido de fazer uma seleção de falas significativas dos ribeirinhos. Da análise do romance resultaram também observações sobre a construção do conjunto da obra dalcidiana, que pode ser descrita tanto em termos de 'ciclo' quanto de roman-fleuve (Bolle, 2011).

Foi precisamente Benedito Nunes (além de Temístocles Linhares) que chamou a atenção para o relevo dado por
Dalcídio Jurandir à fala dos personagens, isto é, às falas de pessoas do povo. O projeto do romancista de organizar um dicionário caboclo é fundamental para o conhecimento da realidade amazônica; por isso, foi escolhido aqui como tema central. Para se poder compreender esse projeto dalcidiano em toda a sua extensão, é preciso, ao mesmo tempo, oferecer uma visão de conjunto do ciclo romanesco ou roman-fleuve -, o que Benedito Nunes conseguiu fazer muito bem, ao escolher um ponto estratégico de observação. Enquanto, no seu ensaio, esse ponto é "Passagem dos Inocentes" (Jurandir, 1984 [1963]), o quinto romance, escrito por Dalcídio no meio do seu percurso, manteve-se aqui a opção pelo último romance, "Ribanceira", que contém uma visão retrospectiva do romancista sobre a sua obra inteira.

A relevância do ensaio de Benedito Nunes (2006) para os estudos de Dalcídio Jurandir reside, sobretudo, em três qualidades de observação: 1) sobre a organização do conjunto da obra; 2) sobre aquilo que o crítico designa como "oscilações" daquele ciclo romanesco; 3) e sobre os tipos de 'falas' e a sua função na obra.

\section{CICLO ROMANESCO}

O Ciclo do Extremo Norte, de Dalcídio Jurandir - a denominação é do próprio autor -, é constituído pelos seguintes dez romances: "Chove nos campos de Cachoeira" (1941), "Marajó" (1947), "Três casas e um rio" (1958), "Belém

BOLLE, Willi. Boca do Amazonas: roman-fleuve e dictio-narium caboclo em Dalcídio Jurandir. Boletim do Museu Paraense Emílio Goeldi. Ciências Humanas, v. 6, n. 2, p. 425-445, maio-ago. 2011.

Autor para correspondência: Willi Bolle. Rua Leonardo Mota, 100, ap. 131. Vila Indiana. São Paulo, SP, Brasil. CEP 05586-090 (willibolle@ yahoo.com).

Recebido em 26/07/2011

Aprovado em 20/08/2011

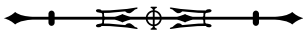


do Grão-Pará" (1960), "Passagem dos Inocentes" (1963), "Primeira Manhã" (1967), "Ponte do Galo" (1971), "Os habitantes" (1976), "Chão dos Lobos" (1976) e "Ribanceira" (1978)2. "Por que se pode aplicar a essa obra a expressão 'ciclo romancesco'?" (Nunes, 2006, p. 245), pergunta o crítico. E ele mesmo explica:

O primeiro sentido corresponde à execução de amplo e continuado projeto, seja o conhecimento do indivíduo em meios e ambientes sociais diversos, como o que Balzac perseguiu em seus vários romances, sob o título geral de "Comédia Humana", seja a comprovação de uma ideia ou tese, como a da hereditariedade fatal das taras em famílias debilitadas pela pobreza e pelo álcool, ordenadora do grande painel naturalista de Émile Zola, os "Rougon-Macquart". Entre nós, Octávio de Faria escreveria uma "Tragédia burguesa" em mais de dez volumes (Nunes, 2006, p. 245-246).

Logo em seguida, Benedito Nunes faz uma restrição: "Mas o ciclo de Dalcídio Jurandir não tem projeto cognoscitivo antecipado nem obedece ao intuito de comprovar conceitos abstratos" (p. 246). Enquanto se pode concordar com a segunda parte desta afirmação, a primeira parte é questionável; inclusive com observações do próprio crítico: "Dez romances (...) que (...) integram um único ciclo romanesco, quer pelos personagens, quer pelas situações que os entrelaçam e pela linguagem que os constitui" (p. 245). Quanto ao aspecto da linguagem, o conjunto da obra de Dalcídio evidencia, como se procura comprovar neste estudo, que ele trabalhou, do início até o fim de sua vida, no projeto de apresentar uma constelação de falas memoráveis do seu povo.

Pelas referências a Balzac e a Zola, fica claro que o projeto dalcidiano se situa dentro da tradição do romance realista e naturalista, que foi retomada no Brasil pelo romance social da década de 1930, ou seja, por autores contemporâneos de Dalcídio, como José Lins do Rego e Jorge Amado - além do já citado Octávio de Faria. Quanto à concepção de um ciclo romanesco, seria importante distinguir entre os autores aos quais essa ideia ocorreu durante o seu trabalho (como Balzac, Lins do Rego, Jorge Amado) e os que aprenderam com os precursores e trabalharam com essa ideia desde o início (como Zola e Dalcídio Jurandir).

\section{ROMAN-FLEUVE (1)}

O "segundo sentido" da expressão "ciclo romanesco" é, como explica Benedito Nunes, o de roman-fleuve. Com este termo se designa

\begin{abstract}
a interligação de cada uma [das obras] com as demais. Tal como acontece em "O tempo e o vento", de Érico Veríssimo (...) ou, ainda, em "Os sonâmbulos", de Hermann Broch, o romance de Dalcídio, com paisagens, personagens e situações comuns, desdobra-se em romances. Em todos eles encontramos uma história (...) de forma circular, porque sempre voltando aos mesmos pontos, em longo percurso temporal, que pode depender da memória de quem narra, lembrança após lembrança (...), como em "À la recherche du temps perdu", de Marcel Proust. Tal como nesta, a memória do narrador, remergulhando na sua infância e na sua juventude, abastece o ciclo do nosso romancista (Nunes, 2006, p. 246).
\end{abstract}

Além dos exemplos citados pelo crítico, vem ao caso lembrar o nome do criador do termo roman-fleuve, Romain Rolland, autor do romance "Jean-Christophe", publicado em dez volumes, entre 1904 e 1912. No caso dessa obra, como também na de seus conterrâneos Roger Martin du Gard, com "Les Thibault” (1922-1940), Georges Duhamel, com "Chronique des Pasquier" (1933-1945), trata-se de uma sequência de romances interligados pela trajetória de um mesmo personagem individual ou de uma família.

Prosseguindo a sua explicação, Benedito Nunes procura sublinhar o vínculo da obra de Dalcídio Jurandir com a de Proust, fazendo contrapeso à avaliação da

2 O único romance de Dalcídio Jurandir que não faz parte desse ciclo é "Linha do Parque" (1959), que narra a luta dos trabalhadores no Rio Grande do Sul.

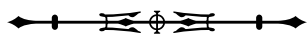


maioria dos críticos que aproximam o romancista paraense de seus contemporâneos brasileiros, notadamente os autores regionalistas:

Se não posso deixar de relacionar o roman-fleuve de Dalcídio com os de Balzac e com os escritos ficcionais do Nordeste nos anos 30 (...), também não me é possível esquecer, por esse lado da introspecção (...), o seu parentesco espiritual com Marcel Proust (Nunes, 2006, p. 246).

Percebe-se aqui uma tendência de valorizar, em Dalcídio, o lado memorialista e introspectivo, em detrimento dos aspectos documentais e de crítica social. Com essa polarização, se entrevê o pano de fundo dessa descrição das características da obra: a controvertida questão de saber qual é a posição que a obra de Dalcídio Jurandir ocupa na literatura brasileira.

\section{O LUGAR DE DALCÍDIO JURANDIR NA LITERATURA BRASILEIRA}

Esta questão é subjacente também à observação seguinte, em que Benedito Nunes opõe a "introspecção proustiana" em Dalcídio à "tendência documental", que predominou no romance brasileiro dos anos 1930:

O ciclo de Dalcídio, enxerto da introspecção proustiana na árvore frondosa do realismo, afastase, graças à força de auto-análise do personagem e à poetização da paisagem, das práticas narrativas do romance dos anos 30, com uma certa constrição do meio ambiente e da tendência objetivista documental, afinadas com a herança naturalista.

De maneira precisa, esse afastamento, já marcante em "Belém do Grão-Pará", se tornará definitivo em "Passagem dos Inocentes" (Nunes, 2006, p. 246).

Há, ainda, uma terceira referência do crítico ao 'traço proustiano' em Dalcídio, que desta vez se desdobra na constatação de uma afinidade da obra do romancista paraense com a de Dostoiévski: "Esse traço proustiano [a saber: a auto-análise de Alfredo no episódio da morte de sua irmãzinha] se adensa com um toque forte, à maneira de Dostoiévski, da mimese de rebaixamento, quando o personagem central descobre que a mãe (...) se embriagava" (Nunes, 2006, p. 247).

Diante dessas comparações reiteradas com Proust e da referência ao grande romancista russo, coloca-se com urgência maior a questão de saber qual é a qualidade da obra de Dalcídio Jurandir. Como que para levar esta questão ao clímax, Benedito Nunes introduz ainda um terceiro autor como termo de comparação, desta vez um brasileiro:

Em 1963, momento da publicação da "Passagem dos Inocentes", encontrei-me, no Rio, com Dalcídio, emocionalmente abalado, senão traumatizado, pela leitura de "Grande Sertão: veredas", de Guimarães Rosa. Escritor nato, ele jamais tentaria imitar Rosa; mas esse impacto estético serviu para despertar nele as mais recônditas potencialidades de sua linguagem, um tanto recalcadas pela vigilância realística, senão política, que exercia sobre o seu estilo, sem que jamais tivesse podido afiná-lo ou desafiná-lo pelo metrônomo do realismo socialista (Nunes, 2006, p. 248).

Com relação ao 'trauma' que é aqui relatado, cabe uma contra-pergunta: como é que um autor pode se sentir abalado pela comparação com Guimarães Rosa, se a crítica atesta à sua própria obra qualidades de Proust e de Dostoiévski? Essa questão só pode ser plenamente esclarecida através de um minucioso estudo comparativo dos procedimentos de construção da obra dalcidiana com os do romancista francês e do romancista russo. Cada um deles seria tema para uma tese de doutorado. Por enquanto, é preciso constatar - ainda que isso possa decepcionar os admiradores de Dalcídio Jurandir - que a sua obra continua não fazendo parte do cânone da literatura brasileira³ .

\footnotetext{
3 Assim, por exemplo, na "História concisa da literatura brasileira", de Alfredo Bosi, existe apenas uma referência de três linhas e meia ao romancista marajoense (Bosi, 2006, p. 426).
}

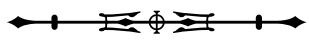




\section{ESTILO DOCUMENTAL E TEOR POLÍTICO- SOCIAL}

O fato de o projeto de Dalcídio Jurandir, em uma de suas principais 'oscilações', filiar-se à poética do romance documental e de crítica social, predominante na literatura brasileira dos anos 1930, implica, sem dúvida, algumas limitações estéticas, como já foi apontado pela recepção. A boa alternativa, no entanto, não é isolar o 'estético' do seu contexto histórico, social e político. $\bigcirc$ forte cunho documental ou semi-documental da obra de Dalcídio não é necessariamente algo negativo. Pelo contrário, ao retomar a tradição brasileira do romance como "forma de pesquisa e descoberta do país" (Candido, 1981, II, p. 112) - juntamente com elementos de invenção poética, a serem especificados mais adiante -, a sua obra abre profícuas perspectivas de diálogo com as ciências sociais.

É o que acontece claramente no último romance de Dalcídio, "Ribanceira" (1978). O seu cenário éa vila de Gurupá, que nasceu a partir de uma fortaleza, assim como Belém, mas está situada diretamente à margem do rio Amazonas, num lugar estratégico, a partir de onde se podia controlar o acesso à bacia amazônica. Essa pequena cidade é representativa para a cultura cabocla na Amazônia em geral, como se vê pelo fato de ela ter sido escolhida tanto pelo romancista Dalcídio Jurandir, no referido romance, quanto pelo antropólogo Charles Wagley, que foi interlocutor do romancista e realizou ali uma pesquisa paradigmática, intitulada "Uma comunidade amazônica” (1956). Enquanto Wagley chama a cidadezinha de "Itá", Dalcídio referese a ela como "Ribanceira".

A ação do romance se passa em 1929/1930, quando o autor trabalhava em Gurupá como secretário do intendente, nomeado pelo governo do estado. Essa é também a função de Alfredo, o protagonista do romance, que assume as tarefas de uma figura de sondagem e de um observador participante. O trabalho de campo realizado por Wagley, no final dos anos 1940, fornece dados que permitem uma visão geral daquela comunidade: sua história econômica e social, os meios de vida e as relações entre as classes, os costumes e o embate entre as crenças dos caboclos e a ciência moderna - tudo isso com o objetivo declarado do pesquisador de encontrar uma saída para a situação de subdesenvolvimento.

Já a constelação dos personagens posta em obra pelo romancista não visa um retrato da sociedade local por inteiro, mas um recorte com representantes do poder público, por um lado, e por outro, com pessoas que sobrevivem à margem. Por meio dessa polarização entre dominadores e dominados (como acontece em outros romances de Dalcídio), acentuam-se as relações de poder. Há um episódio - o das autoridades repartindo a carne no Mercado (Jurandir, 1978, p. 185-192) - que é um retrato simbólico da sociedade dividida em duas classes: os que comem e os que não comem carne. Quanto aos encontros sociais, aos costumes, aos rituais e às festas, o romance dá maior concretude às informaç̧ões da pesquisa antropológica. Esta, por sua vez, ajuda a compreender as estruturas de familia, o sistema de compadrio, a organização das festas, as lendas e os mitos regionais descritos no romance. Desta forma, os textos do antropólogo e do romancista dialogam entre si e se complementam.

\section{AS “OSCILAÇÕES” EM DALCÍDIO}

Voltando ao estudo de Benedito Nunes: quais são as 'oscilações' que, segundo ele, caracterizam o ciclo de Dalcídio? Há quatro oscilações explicitamente designadas como tais:

A primeira oscilação do ciclo é a que vai (...) do rural ao urbano, de Cachoeira (...) à metrópole paraense (Nunes, 2006, p. 245).

A segunda oscilação do ciclo é a que vai da descrição da realidade rural ou urbana à sua recriação poética (Nunes, 2006, p. 247).

Nessa recriação poética da paisagem urbana, alternam-se (...) a fabulação e a rememoração, pólos da terceira notável oscilação desse ciclo, cunhando o seu porte altamente memorialístico (Nunes, 2006, p. 247).

Mas por esse mesmo lado, que acentua o caráter memorialista da obra (vejam-se os trechos de frequentação do Ginásio (...) em "Ponte do Galo" e "Os habitantes", a descrição dos meninos capinadores

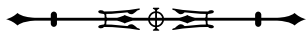


de rua, a morte de um carrossel do interior em "Chão dos Lobos"), destaca-se a oscilação do ciclo entre o individual e o coletivo (Nunes, 2006, p. 249).

A primeira oscilação diz respeito aos cenários dos romances. A ação das três obras iniciais se passa na ilha de Marajó, especialmente nas vilas de Ponta de Pedras (onde o autor nasceu) e em Cachoeira do Arari (onde ele passou a maior parte de sua infância), e no seu entorno fluvial e rural. Nos seis romances seguintes, a ação se transfere para a capital do estado, mas só em "Belém do Grão-Pará" o palco é a área central da cidade; os outros cinco, ou seja, metade da obra de Dalcídio, se passam na periferia de Belém, entre o Igarapé das Almas e a Ponte do Galo. Nestes romances, ocorre um constante vai-e-vem dos personagens entre a capital e o Marajó, juntamente com uma superposição da cultura urbana e a do interior, que é própria da periferia. $\bigcirc$ último romance, "Ribanceira", é o único em que o cenário se desloca para a vila de Gurupá, como já foi visto, abrindo com isso uma perspectiva para toda a hinterlândia amazônica.

Sem dúvida, a recriação poética, que, segundo Benedito Nunes, caracteriza a segunda oscilação em Dalcídio, é uma qualidade estética (que é aumentada ainda por vários instantâneos surrealistas), mas a descrição nos moldes realistas é igualmente importante para o conhecimento da Amazônia. "Ribanceira" é construído de uma forma que lembra um roteiro de pesquisa. $\bigcirc$ leitor vai conhecendo aquela comunidade amazônica, acompanhando, juntamente com o protagonista Alfredo, os guias e informantes locais, como o coletor federal, o juiz, o promotor e o porteiro da Intendência. Surge, assim, um perfil topográfico dessa vila à margem do rio Amazonas, com detalhes como o trapiche, o traçado das ruas, os prédios públicos (o fortim, a intendência, o mercado, a igreja), as residências de autoridades e comerciantes, os barracos dos pobres e miseráveis, e os cemitérios.

A isso se acrescenta um retrato da época histórica, a passagem da década de 1920 para a de 1930, que é evocada por meio de elementos concretos de uma micro- história. "Aquele apito", de que fala o comerciante, seu Bensabá (Jurandir, 1978, p. 183), é a lembrança traumática do anúncio do colapso dos preços da borracha, em 1912; assim como a referência da agente de correio, Dona Benigna, a um baile com "trinta damas defuntas" (Jurandir, 1978, p. 158) expressa a melancolia coletiva diante do declínio geral da economia, do esvaziamento demográfico e do longo período de estagnação (apenas no final do livro aparecem alguns sinais de reestruturação, com a exploração da madeira). Expressões do arruinamento são também os pardieiros de habitantes, como o oficial de justiça ou o prédio da Intendência, uma espécie de catálogo da decadência. A inspeção dos cemitérios é uma alegoria do abandono geral em que vive "esta cidade [que] é toda-toda-cemitério" (Jurandir, 1978, p. 40). A própria denominação de "Ribanceira" sugere uma recaída do espaço urbano nos domínios da selva.

\section{FABULAÇÃO E REMEMORAÇÃO}

A numeração das oscilações realçadas por Benedito Nunes em Dalcídio vai apenas até a terceira, que é caracterizada como alternância entre a 'fabulação' e a 'rememoração'. A ausência de numeração na quarta referência (ao "caráter memorialista") faz surgir uma dúvida: será que se trata de um desdobramento da terceira oscilação ou de um novo tipo de oscilação, que se dá "entre o individual e o coletivo"?

Para esclarecer essa dúvida, é preciso ver o que o crítico entende por "fabulação":

\begin{abstract}
Chamamos de fabulação da narrativa a resultante da elaboração de uma história pelo discurso que a exprime mediante o ato de narrar, a narração propriamente dita, como voz de quem conta, encadeando os fatos numa sequência de ordem temporal. Em geral, a voz do narrador é neutralizada pela dos personagens a que dá iniciativa, seja quando monologam, seja quando dialogam (Nunes, 2006, p. 248).
\end{abstract}

A fabulação é, pois, o resultado do trabalho do narrador, cujo pólo oposto é a rememoração por parte dos personagens. Como as referências fornecidas 
pelo próprio crítico, tais rememorações podem ser exemplificadas pelas lembranças de Dona Celeste, em "Passagem dos Inocentes", ou de Dona Abigail, em "Primeira Manhã", ou ainda por Alfredo, em "Ponte do Galo".

A partir de "Passagem dos Inocentes", explica Benedito Nunes, ocorre uma "requalificação da narrativa pela linguagem", que se manifesta na "adesão da voz de quem narra à fala dos personagens, o que leva a um grau de máxima aproximação o ato de narrar e a maneira de ver e sentir o mundo de cada um deles"; ou seja, os personagens entram em "concorrência com o ponto de vista onipresente de Alfredo" (Nunes, 2006, p. 249), que está próximo da posição do narrador. Isto acarreta uma dupla reestruturação: 1) os personagens assumem o ato de narrar, ou seja, a voz do narrador individual é substituída por uma voz coletiva; em outras palavras, não é mais a fabulação que comanda as falas dos personagens, mas são elas que passam a conduzir a narração; 2) com isso, muda também o caráter memorialista da obra: as falas dos personagens que sustentam a rememoração passam a ser cada vez mais as de um coletivo presente. O estudo direto das falas tornará mais claro esse tipo de 'oscilação' - um termo que implica dúvida e movimento, como também liberdade de opção para representar os movimentos da História.

\section{A IMPORTÂNCIA DAS FALAS EM "PASSAGEM DOS INOCENTES"}

O enfoque de "Passagem dos Inocentes" como a obra em que se dá a "requalificação da narrativa pela linguagem", e a escolha deste quinto romance de Dalcídio como ponto central de observação do ciclo inteiro, permite a Benedito Nunes esboçar um instrutivo retrospecto sobre os quatro romances anteriores:

[P]elo uso não só de termos locais ou regionais (...), a narrativa do nosso autor sempre primou, desde "Chove nos campos de Cachoeira" (1941), pelo relevo dado à fala dos personagens, como um dos principais dados da atestação documental da realidade, também preeminente em "Marajó" (1947), "Três casas e um rio" (1958) e "Belém do Grão-Pará” (1960) (Nunes, 2006, p. 248).

É de se notar que aqui o crítico valoriza o aspecto 'documental' em Dalcídio, que tem sido um ponto controverso na recepção da obra pela crítica. Além disso, ele deixa claro que o uso de um vocabulário amazônico palavras como 'panema', 'mundiar', 'pitiar' ou expressões como 'mea filha', 'axi!', 'esposarana' - é apenas um dos lados do trabalho linguístico do escritor. O outro lado, que é a passagem qualitativa do material linguístico para a criação literária, se dá "através da fala dos personagens, na fabulação da narrativa e no seu desenvolvimento romanesco" (Nunes, 2006, p. 248).

Essa 'requalificação' literária é ilustrada com vários exemplos de "Passagem dos Inocentes". Por meio da afluência de 'falares' e 'dicções' de um grande número de personagens, a narrativa se pluraliza: "Essa pluralização se torna patente com a entrada, na estrutura do romance, das múltiplas vozes em tumulto de uma multidão rebelada, protestando contra o descaso das autoridades responsabilizadas pela morte de numerosas crianças, vítimas de um surto epidêmico" (Nunes, 2006, p. 250).

Como se vê, Benedito Nunes destaca aqui um aspecto da obra que revela Dalcídio Jurandir como um autor politicamente engajado em favor de causas públicas, sem conotações de proselitismo. Com efeito, o romance "Passagem dos Inocentes" é uma narrativa em que o lado memorialista, representado pela recordação da "fuga a bordo" por parte de Dona Celeste, coexiste de modo equilibrado com a representação de uma cena que trata dos problemas sociais da cidade de Belém no tempo presente da ação.

Nas considerações do crítico, passam, então, para o primeiro plano a pólis e a política:

É uma cena aberta na Praça da República. Ao pé da estátua alegórica republicana, aglomeram-se diferentes grupos de trabalhadores, homens e mulheres, que envolvem Alfredo (...). A narrativa

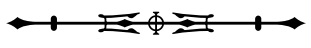


continua em distintiva forma dialogada, em que se alternam Uma voz, A mulher grávida, A primeira voz, A voz de outra mulher (...). Faixas se sucedem: Sociedade Beneficente dos Funileiros, Federação das Classes em Construção Civil, União dos Caldeireiros de Ferro (Nunes, 2006, p. 250).

Esses "diversos falares em tumulto", essas "faixas de protesto" e toda essa "polifonia de vozes" configuram o que o crítico chama de um "transbordamento dramático, a rigor, cênico, da ação" (Nunes, 2006, p. 250).

Cabe aqui lembrar uma experiência em que o teor dramático de "Passagem dos Inocentes" foi explorado mais detalhadamente. Em 2009/2010, foi realizada uma adaptação cênica do romance, por professores e alunos da escola estadual Dr. Celso Malcher, no bairro de Terra Firme, em Belém, coordenada pelo autor deste artigo ${ }^{4}$. A elaboração do roteiro cênico exigiu uma atenção especial para as falas dos personagens, uma vez que se trata de selecionar as mais expressivas; foram essas também que proporcionaram o maior prazer aos atores durante a interpretação. Houve duas apresentações públicas (em 6 de novembro de 2009, na escola, e em 15 de abril de 2010, na Universidade da Amazônia - UNAMA). A oficina dramática mostrou que a forma teatral, por ser essencialmente lúdica, coletiva e voltada para a socialização do conhecimento, é muito apropriada para despertar o interesse pela leitura das obras de Dalcídio Jurandir. A partir dela, é possível se desenvolver a capacidade de percepção da realidade amazônica e os recursos para expressá-la. Como próximo passo, o grupo planeja, para o segundo semestre de 2011, uma apresentação cênica dos romances "Primeira Manhã" e "Ponte do Galo".

É o momento de citar novamente Benedito Nunes, que completa a sua análise de "Passagem dos Inocentes" com uma prospecção no sentido de explicar como a reestruturação da narrativa repercute nos quatro romances seguintes: "É como se em 'Primeira Manhã', 'Ponte do
Galo', 'Os habitantes', 'Chão dos Lobos' a dialogação conduzisse a narração e com a narração se confundisse como maneira de ver e de sentir o mundo dos personagens em afluência. Os personagens afluem e confluem seus falares, suas dicções" (Nunes, 2006, p. 249).

Ou seja, as falas dos personagens vão crescendo em importância, a ponto de elas se tornarem os principais componentes da ação narrada. Para complementar o estudo de Benedito Nunes, seria importante investigar a importância das falas no último romance do ciclo de Dalcídio Jurandir, em "Ribanceira".

\section{A IMPORTÂNCIA DAS FALAS EM "RIBANCEIRA"}

Retomando a comparação entre "Ribanceira" e o estudo de Charles Wagley, pode-se dizer que o principal traço diferenciador do romance de Dalcídio em relação à pesquisa antropológica é a atenção dada à linguagem dos habitantes daquela comunidade amazônica.

Neste ponto, vem ao caso lembrar os relatos de viagem sobre a América Central e a América do Sul de Alexander von Humboldt (1989 [1810-1813], 1970 [1814-1825]), que estudou as línguas das tribos indígenas da planície amazônica com a mesma dedicação que a escrita dos povos das Cordilheiras, destacando, assim, implicitamente, a língua como documento mais importante da história da humanidade. Numa passagem memorável de sua "Relation historique du Voyage aux Régions Équinoxiales du Nouveau Continent", ele fala de uma tribo às margens do Orenoco, que se extinguiu poucos anos antes de sua chegada e cuja língua era falada, então, apenas por um papagaio ${ }^{5}$. Essa história emblemática foi adaptada por Mário de Andrade e incorporada à composição de "Macunaíma" (1928), onde o narrador se propõe "contar a história" "de nossa gente" para "preserv[á-la] do esquecimento" (Andrade, 1978, p. 148). Dentro dessa tradição, mas

\footnotetext{
${ }^{4}$ W. Bolle, 2011, especialmente a parte final, intitulada: "Theaterarbeit an der Peripherie" (Trabalho teatral na periferia).

5 “Cette nation (...) s'éteignit peu à peu ainsi que son langage. Les dernières familles des Aturès existoient encore en 1767 (...): à l'époque de notre voyage [1800], on montroit à Maypurès (...) un vieux perroquet dont les habitans disent 'qu'on ne comprend pas ce qu'il dit, parce qu'il parle la langue des Aturès'” (Humboldt, 1970, v. II, p. 598-599).
}

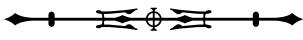


com outros procedimentos literários, também o autor de "Ribanceira" se propõe como objetivo guardar a memória da língua dos ribeirinhos.

Pela sua composição, o romance é um roteiro ao mesmo tempo antropológico e poético. Os episódios da narrativa são as caminhadas do protagonista Alfredo pela cidade (inspeções profissionais e passeios), a rotina do expediente, as refeições cotidianas, jantares e recepções festivas, visitas, encontros casuais e a festa popular no final. Esses episódios proporcionam os mais diversos contatos com os habitantes, lembrando as entrevistas de um antropólogo com seus informantes. $\bigcirc$ enredo do romance pode ser resumido como uma caminhada do protagonista, de fala em fala - como, aliás, já se esboçou no romance de estreia, com Eutanázio, que é, ao lado de Alfredo, o personagem-guia.

Em "Ribanceira", a importância das falas na composição da narrativa chegou a tal ponto que se pode dizer que o romancista criou 'personagens-falas'. Uma excelente ilustração desse conceito encontra-se na escrita hieroglíica asteca, apresentada por Alexander von Humboldt (1989)em "Vues des Cordillères et Monuments des Peuples Indigènes de l'Amérique" (primeira edição de 1813). No tableau XII, que mostra uma genealogia de príncipes, aparece diante da boca de alguns personagens uma pequena língua, que falta em outros. Essa língua é um sinal de que se trata de seres vivos, pois, segundo os astecas, viver é falar.

"Ribanceira" é um fluxo narrativo contínuo de 322 páginas, uma montagem dos referidos episódios contendo um conjunto de falas que o narrador e o protagonista conseguiram captar e registrar. Como resultado, apresentase um detalhado retrato da sociedade e da cultura locais, expressas, sobretudo, por essas falas. A atenta escuta das falas do povo e o fato de Dalcídio Jurandir dar voz aos habitantes da ribanceira representam um avanço qualitativo em relação ao projeto sertanejo e amazônico de Euclides da Cunha, o qual, na maioria das vezes, fala em nome das populações locais.

\section{CULTURA ESCRITA E CULTURA ORAL}

Como 'secretário', o protagonista Alfredo é explicitamente caracterizado como um representante da cultura escrita, num duplo sentido. Enquanto 'escrevente', ele é um profissional que usa a escrita como um mero instrumento, a serviço do aparato burocrático do poder; já enquanto alter ego do romancista, esse secretário torna-se um 'escritor' livre e independente, que trabalha a língua como um medium de expressão poética e de reflexão crítica ${ }^{6}$ - além de ser também um tradutor entre a cultura escrita e a cultura oral.

Na vila às margens do Amazonas, circulam duas formas antagônicas de língua: por um lado, a língua falada pelos ribeirinhos, como expressão da cultura oral das camadas populares, ou seja, o português coloquial, com elementos indígenas e africanos; por outro lado, a norma culta, sobretudo na forma da linguagem escrita da administração. Disso resultam, às vezes, formas misturadas, como nesta fala da lavadeira Daria-Mora-com-o-Diabo, que recebe a visita de Alfredo em seu barraco na beira do igarapé: "Agora que o senhor está aí (...), licença que lhe pergunte: as informações que o senhor teve desta minha fraca pessoa? Leu no edital do Trapiche? Ouviu dum boca quente?" (Jurandir, 1978, p. 263).

De forma jocosa e irônica, aparecem aqui, lado a lado, os dois tipos de linguagem que caracterizam a cultura ribeirinha: a fala oral e coloquial do povo, com a referência à praxe geral das fofocas ("boca quente"), e a escrita ("o edital"), com a qual o aparato administrativo marca a sua presença num lugar de circulação pública ("o Trapiche").

\section{UM DICTIO-NARIUM DA CULTURA AMAZÔNICA}

Como mostra o exemplo citado, o tipo de conhecimento que procura o 'escritor' Dalcídio Jurandir, por meio do seu alter ego, o secretário 'escrevente' Alfredo, é uma intensa

\footnotetext{
6 Seria tentador associar essa oposição entre 'escritor' e 'escrevente' com a dupla conceitual 'écrivain' e 'écrivant' em Roland Barthes; mas existe uma nítida diferença semântica entre 'escrevente' e 'écrivant', uma vez que este termo é aplicado pelo crítico sobretudo ao intelectual (Barthes, 1964, p. 147-154: "Écrivains et écrivants").
} 
escuta da comunidade ribeirinha enquanto espaço linguístico. Nos vários ambientes desse cenário, o escrevente-escritor escuta e registra tipos de falas: de representantes do poder público, ou seja, do aparato burocrático-administrativo, de proprietários e comerciantes, e também de gente das camadas de baixo. Com isso, o romance torna-se um repositório de conversas, fofocas, denúncias, brincadeiras, estórias galantes, lendas, crenças e mitos, revelando a mentalidade, as imagens de desejo, os conflitos e os saberes dos habitantes. É um espaço polifônico e democrático, pois o direito à fala é concedido a todos.

O projeto de Dalcídio Jurandir consiste em organizar com o conjunto desses materiais um dictio-narium da cultura amazônica. Não se trata de um 'dicionário', no sentido convencional de um 'vocabulário', mais ou menos exaustivo, em ordem alfabética, mas de algo mais profundo. O dictio-narium, no sentido do linguista e pesquisador da cultura popular Jakob Grimm (1966, p. 311), é uma coletânea de dictiones, isto é, de falas exemplares e citáveis, que merecem ser guardadas na memória coletiva.

Esse sentido etimológico e primordial da palavra 'dicionário' é corroborado pelo próprio Dalcídio Jurandir, como mostra esta passagem de "Primeira Manhã", que é o romance em que se discute a questão da educação e da formação:

- Mamãe, (...) mande (...) o Dicionário de Latim, mas mande escondido do papai (...). No chalé, o Dicionário era que nem uma pessoa, embora mitológica. Uma semana antes da volta a Belém, de noite, no chalé, sonhando com o Ginásio, embalava-se na rede, roçando o pé na estante (...). O pé tocava na lombada do Dicionário. Era tocar e irrompiam do livro aquelas vozes mortas que tantos séculos falaram a língua ali sepultada. Pôs-se a escutar o imenso coro, o numeroso latim dos oradores e das legiões, das orgias e dos templos, dos césares e dos santos... Sobre aqueles séculos do falar latim, embalavase (...), o pé na tumba sonora. (...) $\bigcirc$ chalé lhe pareceu o tempo morto, o museu das vozes mortas; abeirou-se do rio, este sim, tão vivo, tão recém-nascido. (...) Não, direito não era tirar escondido aquele maciço catálogo de fala antiga. (...) Semelhante latim não valia no Ginásio, não era o mesmo do professor Menendez. Ficasse sempre à disposição do pai (...). Era o seu pé de meia da ilustração (Jurandir, 2009, p. 39-40).

A relação aqui descrita do protagonista Alfredo com o dicionário é uma alegoria da relação do escritor Dalcídio Jurandir com a língua e a cultura da Amazônia, uma síntese do seu projeto literário e cultural.

De fato, o dicionário para ele não era um mero 'vocabulário' (como pode ter sido para o professor do Ginásio, que ostentava erudição) nem um mero instrumento de consulta (como para o pai, que gostava de exibir a sua ilustração), mas uma coletânea de "falas", de "vozes", no limite, era "uma pessoa", tão concreta que podia até se "tocar". É verdade que são vozes "mortas", há "tantos séculos", é uma "língua sepultada" numa "tumba", e guardada num "museu", ao qual se opõe o caráter "vivo" do rio. Mas, por outro lado, com a sua força "mitológica", aquela fala "antiga" atravessa "tantos séculos" e sobrevive, graças ao medium da escrita que ressurge, com nova energia, no escritor do tempo presente, que, assim como o rio, tem o poder de fazer "renascer" aquelas vozes, de torná-las "vivas".

Com essa conjunção entre o dicionário como 'catálogo de falas' e de 'vozes', e o rio como um ser vivo, "recém-nascendo" e fonte de constante renovação, Dalcídio Jurandir resume, de maneira muito expressiva, o seu projeto de retratar a cultura dos habitantes da Amazônia em forma de um dictio-narium, depositado nos dez volumes do seu roman-fleuve.

Seria desejável desenvolver um estudo que pudesse reunir o conjunto desse amplo retrato dalcidiano da cultura amazônica por meio de suas falas - inclusive as que tratam dos "oradores" e das "orgias", dos "templos" e dos "santos", nesta região. Por enquanto, será apresentado aqui algo mais modesto: uma amostra de exemplos concretos do dictio-narium contido no último romance do autor, com a menção paralela de alguns elementos metodológicos e teóricos que fazem parte de sua antropologia poética.

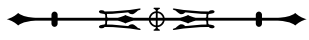




\section{"OUVIR OS PODRES LOCAIS"}

$\bigcirc$ trabalho do romancista de escutar e registrar as falas que representam a cultura ribeirinha é apontado indiretamente em uma das falas iniciais do intendente, que explica ao seu secretário Alfredo, recém-chegado, o sentido de sua missão: "acomodar aquelas coisas no Município". O que significa "pacificar a família daquela terra" e implica "resignar-[s]e" a "ouvir no meio deste entulho os podres locais" (Jurandir, 1978, p. 35). É exatamente esse trabalho de ouvir - e registrar - que é realizado pelo protagonista secretário durante sua estadia na ribanceira. A todo momento, ele é abordado por pessoas, na maioria letrados, que lhe expõem os conflitos nos quais estão envolvidos e lhe solicitam o seu apoio. Um dos embates mais agudos naquela vila é a hostilidade com que o coletor federal (o "Sede de Justiça") vê a pessoa do juiz:

- Esse salteador de toga e arminho (...). Esse espoliador de cem viúvas contadas a dedo, uma a uma, de mil órfãos cujos nomes posso lhe dizer um a um (Jurandir, 1978, p. 58).

- Pois [o juiz] me arrasa o Município, me desonra a Comarca, e sempre impune, e sempre intocável? (Jurandir, 1978, p. 61).

- Tudo (...) recolhi, documentei, selei, para o processo (...) tamanho dos crimes dele, pela acumulação das provas (Jurandir, 1978, p. 62).

tom da acusação é tão exacerbado que acaba enfraquecendo a posição do acusador, o qual tem consciência disso e declara num tom de amarga auto-ironia: "Será que estou berrando no deserto?"; "Tudo que recolhi, documentei (...) é meu delírio?" "Sou apontado pelas ruas (...) como o Sede de Justiça" (Jurandir, 1978, p. 61-62).

A réplica do juiz é introduzida em forma de uma montagem contrastiva. Ele se defende das acusações mostrando desprezo pelo inimigo, e procura ganhar a simpatia do intendente e do secretário ao lhes fazer um convite para uma excursão erótica, em tom divertido e propositadamente vulgar:
- Limpo o meu sim-senhor com os papéis do processo dele. (...) Repugna-me ter de falar nos rombos da Coletoria Federal (...) (Jurandir, 1978, p. 70-71).

- É de minha obrigação guiá-los e indicar-lhes os pontos de recreio. (...). Aqui para o dom donzel: já ouviste falar do Itaperera, lá, onde é o xirizal? (...) $\bigcirc$ gineceu, xiris em penca. Vamos no meu bote (...) por essas ilhas, igarapés e beiradas. (...) No bote, fico nu de corpo e alma (Jurandir, 1978, p. 74).

\section{ESTÓRIAS GALANTES}

Numa sociedade em que o elemento erótico estáà flor da pele e onde "as relações conjugais [são] extremamente instáveis" (Wagley, 1988, p. 183), um ingrediente imprescindível do retrato dos costumes locais são as estórias galantes. À guisa de introdução, pouco depois de desembarcar na ribanceira, Alfredo ouve, narrado pelo intendente, o caso do fiscal de Imposto de Consumo, "já passando dos sessenta", com a jovem Bi, filha do ex-intendente, coronel Cácio:

\begin{abstract}
A lábia do Fiscal ganhou o casarão. (...) Uma noite, (...) a moça abre o soalho do seu quarto ao galante ancião. (...) [O irmão da Bi] vê o Fiscal entrando e toda a casa num rebuliço acordou. $\bigcirc$ pai tira a 44 da parede, também se armou o primo (...). Atezinho o nosso porteiro (...) acudiu de facão em punho. (...) A desafronta, dirigia o Prefeito de Polícia (...). Bandido, se tens topete, pula, e o velho Fiscal salta da rede (...), meu camisão? (...) Não saia por debaixo do soalho,
\end{abstract}

lhe peço, pedia a Bi. Mas não foi por onde entrei? Sim, como meu namorado. Tem que sair agora como uma autoridade (...). Fiscal Federal, que é que não vai dizer o comércio? Pela porta, que atirar, não atiram, se atirarem, morremos juntos. Enfrente meu pai, enfrente meus irmãos, mas saia pela porta. Vista o camisão (...) e vamos de braço (Jurandir, 1978, p. 36-37).

Arma-se, assim, uma cena intensamente dramática, em que a vida íntima das pessoas é exposta ao público espectador e onde cada personagem assume o papel que lhe parece mais conveniente: os homens da família da Bi como guardiães de sua honra, e a moça no papel da apaixonada,

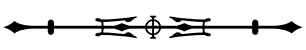


disposta a morrer pelo seu amor. Já para o Fiscal sessentão, sobra a exposição ao ridículo geral: ele que imaginava viver a sua aventura erótica na calada da noite, é exibido diante dos olhos de todos num figurino grotesco: a autoridade federal, em vez de vestir a toga, aparece de camisão.

Os referidos episódios, o do fiscal federal em trajes íntimos e o do juiz nu em pelo, são retomados numa conversa jocosa entre Alfredo e $\mathrm{Bi}$, durante um passeio noturno pela ribanceira, na noite em que foram convidados para um baile na casa de Dona Benigna, a agente do correio. Mas, como o maestro músico não compareceu, todos tiveram que sair em busca dele. Alfredo provoca a Bi, em tom de brincadeira, referindo-se a uma moça que ganhou do juiz uma ilha em troca de favores: "[Alfredo:] - Ganhou do Juiz a ilha... [Bi:] - Ah, que o senhor mal chega e já sabendo de cor os nossos maus costumes?" (Jurandir, 1978, p. 138).

São, portanto, os temas da conversa os costumes daquela vila. Pertencendo a uma das familias mais consideradas, a Bi assume plenamente tanto o 'amor livre' quanto o fato de ser uma 'moça falada'. Com uma boa dose de autoironia, ela se dispõe a constar como uma amostra dos costumes locais, não deixando de manifestar, ao mesmo tempo, a sua crítica em relação aos bem-pensantes e aos hipócritas. Com tudo isso, ela se torna uma das principais informantes do escreventeescritor que retrata esses modos de vida:

- Que tenho eu de mais que lhe interesso? A fama? Quer mandar um ofício sobre os maus costumes desta cidade? (Jurandir, 1978, p. 113).

- Sou ou não sou a mal-afamada? (Jurandir, 1978, p. 118).

- Saiba, meu senhorzinho, que ela [D. Benigna] só me tolerou no grande baile dela, por pura carência de dama (Jurandir, 1978, p. 132).

\section{"AQUI É EXPRESSAMENTE PROIBIDO LER E ESCREVER"}

Na figura de um dos letrados locais, Dalcídio Jurandir apresenta algumas reflexões de interesse geral sobre a relação entre a cultura oral e a cultura escrita naquela comunidade amazônica, a relação entre o escutar e o falar e, por outro lado, o ler e o escrever. Um episódio emblemático é a visita de Alfredo à casa do promotor: "O Promotor mostra os dicionários de francês, exibe o papagaio que diz chérie ma petite-fille" (Jurandir, 1978, p. 269).

Nesta passagem aparecem lado a lado o 'dicionário', no sentido convencional de 'vocabulário', e uma amostra do dictio-narium: a frase de um papagaio que fala francês. É uma justaposição jocosa entre um documento da cultura escrita e da cultura oral. Ambos demonstram o menosprezo do dono em relação ao português como língua oficial da Amazônia brasileira. O promotor manifesta enfaticamente a sua preferência por aquela outra língua e cultura, que ele considera como superior: "- Franceses, sim, que deveriam colonizar este país, estaríamos hoje falando como civilizados. Sinto-me muita vez levado para aqueles bosques de Alexandre Dumas, para a Corte. (...) $\bigcirc$ promotor desembainha a espada: (...) - É a minha viagem a Paris! A Paris!" (Jurandir, 1978, p. 271-272).

No meio da vila arruinada às margens do rio Amazonas, o promotor vive o seu devaneio de fazer parte da cultura francesa, que representa, para ele, o supra-sumo da civilização. A sua fantasmagoria é a versão interiorana do sonho da classe dominante de Belém, na Belle Époque, de transformar a sua cidade em uma Paris nos trópicos ou 'Paris n'América'. O elemento satírico neste episódio, que mostra o letrado local sonhar com a substituição de um colonizador por outro, reside no fato de ele (e por tabela, também a elite da região) não saber imaginar a 'civilização' de outra forma a não ser como uma relação de 'colonizador' e 'colonizado'. A visão truncada que o promotor tem da cultura e da civilização aparece de forma escancarada nesta declaração: "- Este barranco só embrutece. (...) Não perca seu tempo. Coloque no Trapiche este aviso: Aqui é expressamente proibido ler e escrever" (Jurandir, 1978, p. 271).

Esta frase não é uma forma irônica de denunciar a falta de acesso da população pobre à educação - o que é uma preocupação constante na obra de Dalcídio Jurandir.

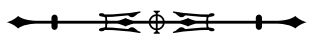


Trata-se, pelo contrário, da postura de um burocrata, que se vê a si mesmo como parte da elite, no papel de um homem 'culto' e de um colonizador, e que desqualifica os caboclos em seu conjunto. Segundo ele, o interior da Amazônia é um lugar avesso a qualquer tipo de civilização. Além de negar que os ribeirinhos possam ter uma cultura própria, ele deixa claro que não vale a pena fazer ali qualquer investimento educacional. De forma sarcástica e brutal, esse personagem, que se manifesta contra o acesso dos caboclos à cultura escrita, representa o pensamento daqueles "burocratas, famílias de comerciantes e outros membros da classe mais alta" que acham que "a educação das camadas mais baixas ameaçaria sua posição dominante" (Wagley, 1988, p. 268-269).

\section{OS REPRESENTANTES DO PODER}

Em seu contato cotidiano com os representantes do poder público, durante o expediente na Intendência e na rotina dos atos oficiais, o secretário Alfredo inteira-se da mentalidade dos funcionários e adquire uma visão por dentro do aparato burocrático que atua e autua por meio da escrita. Uma peça típica desse aparato é o porteiro, seu Dó, que exibe, a todo momento, as chaves como insígnia do seu poder e que é zeloso ao excesso. Um exemplo de sua mania de cumprir a lei além da conta é este retrato satírico:

Entra o seu Dó, com as chaves na mão, contando que o seu Remundo da Purificação tem de levar os acaris ao Mercado.

- O que só fiz, Secretário, fiz ver a ele a lei. (...) Remundo (...) cisma que está acima da lei. (...) Desacatou mea autoridade. Não estamos mais na administração passada (...). Agora tudo é melhoramento. (...) $\bigcirc$ abuso precisa dum corretivo. Sei que o senhor me dá mão forte, Secretário. Posso autuar? (Jurandir, 1978, p. 241-242).

Como nas narrativas de Kafka, onde mesmo os representantes mais subalternos do aparato do poder, como os porteiros, e sobretudo eles, têm plena consciência de sua autoridade e a fazem valer nos mínimos detalhes, também este porteiro da ribanceira se sente imbuído da força da instituição e se compraz com a perspectiva de fazer sentir a um ignorante pescador o peso repressor da lei.

Pelo fato de estar hospedado na casa do capitão, que é o chefe de polícia, com quem também costuma almoçar, Alfredo está em contato com ele tanto no ambiente profissional quanto familiar. O retrato do chefe do poder Executivo não é menos satírico que o do porteiro; a começar pelo fato de ele admitir que não conhece a lei: "- Que é que diz a lei, Capitão? (...) - Conheço a lei, não, Secretário" (Jurandir, 1978, p. 169).

O chefe de polícia é um torturador de ofício. Quando mantém encarcerado um sujeito que ele suspeita de ser ladrão, e o deixa sem comer, a ponto de a população inteira sentir compaixão e pedir a libertação do preso, ele cita como justificativa a pseudo-ciência dos 'criminosos natos': "detido é um lombrosiano escarrado. (...) No não confessar já mostra a tara lombrosiana" (Jurandir, 1978, p. 272-273).

Com a mesma crueldade, o capitão age também em casa, contra sua esposa. Eis o que a empregada segreda a Alfredo, e o que diz o narrador, completando o retrato:

\begin{abstract}
- Olhe, Secretário, ele [o Capitão], de dente ferrado, risca o peito dela [de Dona Almerinda, a esposa] com ponta de canivete. (...) Rameira, que ofensa é? (...) é mesmo nome feio, Secretário? (Jurandir, 1978, p. 229).

Neste instante, "rameira" escreve o Capitão a punhal no peito de D. Almerinda (Jurandir, 1978, p. 257).
\end{abstract}

Este episódio faz lembrar uma narrativa de Kafka, "Na Colônia Penal", onde o julgamento é inscrito na pele do réu com um instrumento de tortura. É um castigo irremovível que estigmatiza o outro eternamente como transgressor da lei ou, no caso da esposa do capitão, como (suposta) pecadora. É o uso mais cruel e mais perverso que se possa fazer da escrita.

\section{AMOR À TERRA, AMOR AO DINHEIRO}

Para o retrato das principais famílias da ribanceira ficar completo, faltam ainda algumas falas de proprietários e

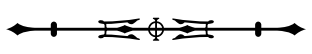


comerciantes. $\mathrm{O}$ seu traço comum é o exibicionismo, o amor ao dinheiro e à propriedade. Como nesta fala do coronel Cácio, "ex-Intendente", "chefe local do PRF, deputado estadual, Coronel da Guarda, dono de gaiolas e seringais, lago e igarapés" (Jurandir, 1978, p. 41), que se gaba de propriedades já perdidas, fazendo par com sua esposa, D. Generosa, que sonha com uma quinta herdada em Portugal. Quando trazem para a mesa do pomposo jantar os acaris moqueados, o coronel exclama: "- Dos nossos lagos. Tivemos lago exclusivo da família, só para consumo de casa, (...) em nossas posses, um lago de pirarucu (...). Com vigia armada. O nosso pescador arpoava, segundo nossas instruções e necessidades" (Jurandir, 1978, p. 85).

Na exibição de glórias do passado, se compraz também o comerciante seu Guerreiro, casado com D. Fortunata. Frustrado e ressentido por ter perdido negócios vultosos e ilícitos para uma concorrente que foi mais esperta, ele conta:

- A empreita não podia ser nossa? Aqui em minha casa que o Presidente [da República] ouviu a ideia de restaurar o Forte. Aqui nesta mesa, tomando café. Partindo de uma pergunta minha: Presidente, V. Exa. pode dar um socorro à nossa terra, ao menos umas obras no Forte? (Jurandir, 1978, p. 205).

As obras do Forte (...). Aqui entre nós, [em política] não me meto, mas mamaram, mamaram grande. (...) Quem mamou foi a [empreiteira] D. Mundiquinha Paiva (Jurandir, 1978, p. 203-204).

Qual é o balanço geral que fazem esses comerciantes da ribanceira na conjuntura econômica em torno de 1930? A sua perspectiva de futuro oscila entre o saudosismo do tempo da borracha e a vontade de deixar o lugar, como se vê por estas duas declarações, aparentemente divergentes, mas que têm em comum o desejo de fugir do presente:

[Seu Bensabá:] - Sobramos da calamidade (...). Do mundo lá fora (...) ainda espero um sinal (...). Ah, todos nós sonhamos, me acredite. Preços subindo, julho chegou, vamos abrir as estradas, põe gente, recomeça aquele tempo (Jurandir, 1978, p. 183-184).

[Seu Guerreiro:] - Pudesse, eu e os meus já estávamos (...) fora daqui. (...) Isto aqui deixa de ser lugar de família. Deus entregou isto ao Diabo (Jurandir, 1978, p. 209).

Todas essas cenas que mostram 'os podres' da classe mais alta confirmam o que Benedito Nunes (2006, p. 250-251) observou sobre "Ribanceira": o ciclo adquire aqui "um porte de sátira social", "o estilo adquire a leveza do transbordamento cômico, os personagens tornam-se caricaturas" e "a História (...) vira farsa".

\section{A SITUAÇÃO DOS POBRES}

O outro segmento da população com o qual o secretário Alfredo entra em contato são os pobres e iletrados. Alguns deles vivem em estado de miséria, como os Seruaia: um pai, chamado Cristo, que depois de viúvo "se acuou na ribanceira" com as três filhas (Jurandir, 1978, p. 316). Eles dependem do que ele caça, mas por infortúnio a espingarda do velho caçador se quebrou. Nessa situação, "encarando o meio-dia a prumo e a seco", Bernarda Seruaia lança um grito de revolta: "- Que que Deus nos deu este desviver? (...) Diabo! (...) com esse Trapiche podre, os gaiolas passam de largo. (...) Põe tua prancha nesta soleira e desembarca o teu jantar, gaiola" (Jurandir, 1978, p. 317).

O que expressa essa moradora da ribanceira é a necessidade extrema em que vive "a maioria das famílias rurais": de "comer mal e de atravessar períodos de semiinanição" (Wagley, 1988, p. 134). Diante dessa situação, o protagonista Alfredo se pergunta, no final: "Que será dos Seruaias (...) que será desta tapera[?]" (Jurandir, 1978, p. 320). De fato, quais são as perspectivas? Qual é a concepção de história que está contida no vasto acervo de falas da cultura ribeirinha reunido por Dalcídio Jurandir?

Uma comparação com a visão de história do antropólogo Charles Wagley, que pesquisou a mesma comunidade amazônica nos anos 1940, talvez possa 
ajudar a encontrar uma resposta. Wagley acredita, em princípio, num avanço da razão, da ciência e do progresso tecnológico e social, mas, ao mesmo tempo, não alimenta ilusões quanto ao tamanho dos obstáculos: "[E]ssa cultura tradicional da Amazônia e o sistema sócio-econômico que a sustentou constituem uma barreira à mudança e à formação da nova sociedade e cultura amazônica que o Brasil espera desenvolver" (Wagley, 1988, p. 15).

"Da história da Amazônia", explica ele, "emergem as razões de sua atual condição 'de atraso'” (Wagley, 1988, p. 282). Trata-se, principalmente, de três fatores: o sistema colonial, que fez da Amazônia uma região produtora de "matérias-primas para mercados distantes, sem uma justa compensação"; o sistema escravocrata, que rebaixou os indígenas e a mão de obra trazida da África a meros instrumentos de produção; e o rígido sistema de classes daí decorrente, com a permanente discriminação dos de baixo (Wagley, 1988, p. 282-283). O principal obstáculo à transformação, segundo Wagley (1988, p. 268-269), é a classe mais alta, "que não desej[a] a transformação social".

Essa avaliação do antropólogo coincide basicamente com a do romancista, embora este não formule projetos para o futuro, concentrando-se na observação do tempo representado. Ora, será que a modernização iniciada nos anos 1960 não trouxe consigo substanciais mudanças em comparação com a situação dos anos 1930 e 1940, diagnosticada por Dalcídio Jurandir e Charles Wagley? Sem dúvida, a Amazônia nos dias de hoje (2011) tem essas duas faces: uma inegável modernização em grande escala e, por outro lado, graves problemas sociais não resolvidos, que decorrem tanto da persistência de estruturas coloniais quanto das contradições da modernização. $O$ projeto de uma transformação social e "uma nova cultura amazônica" é imaginado por Wagley (1988, p. 288) como uma reunião das forças da técnica, da ciência e da indústria modernas com os valores da tradicional cultura popular da região, que devem ser preservados. Mas o que isso significa em termos práticos? Quais são os modelos bem-sucedidos de "conhecimento do modo de vida do homem da Amazônia" (Wagley, 1988, p. 40)?

Quanto ao diálogo com os saberes tradicionais dos ribeirinhos, a partir dos conhecimentos desenvolvidos pela sociedade urbana moderna, o autor de "Ribanceira" desenvolveu um modelo concreto na figura do protagonista Alfredo, o secretário escrevente-e-escritor, que atua como um go-between entre as classes e as culturas. A crítica ainda está no meio da tarefa de descrever os procedimentos poéticos de pesquisa antropológica postos em obra por Dalcídio Jurandir. Como se procura mostrar aqui, os saberes locais não são apresentados pelo romancista numa perspectiva folclórica, mas como um recurso necessário para a população poder sobreviver em circunstâncias muito difíceis.

\section{CULTURA ORAL: DAS LENDAS E FESTAS À HISTÓRIA DA ESCRAVIDÃO}

A maioria dos moradores da ribanceira vive de acordo com as tradições locais da cultura oral, num espaço mental de crenças indígenas e de sincretismo religioso popular. O personagem-guia Alfredo conversa com várias contadoras de estórias, que o põem em contato com o universo amazônico de mitos e lendas, crenças e magias.

Uma das contadoras é a Bi, filha de coronel, mas que se distancia de sua classe de origem ao assumir o papel de uma narradora popular. Na noite de sua longa conversa com Alfredo, ela se apresenta a ele no papel de uma figura lendária da cultura indígena: a matinta-perera, que é uma mensageira do mundo dos mortos: "- Fique sabendo que sou escrito a matintaperera (...). Estou aqui com o senhor fazendo ofício de contadeira do que acontece (...) neste cabuloso beiradão do rio Amazonas" (Jurandir, 1978, p. 119-120).

Combinando com essa atmosfera, ela narra um ritual africano: um despacho de magia negra da ribeirinha Bernarda Seruaia contra uma rival. Ela conclui com uma transfiguração dela e do seu interlocutor em figuras 'encantadas': "- Pois de com pouco me viro em rio e o senhor em peixe, peixe pirarara. (...) - Acabo é jurando que nós já se encantamos" (Jurandir, 1978, p. 123 e 129).

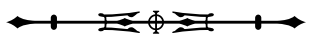


O ouvinte dessas estórias, o protagonista Alfredo, adapta esse molde lendário ao seu próprio caso, respondendo com uma narrativa que é uma versão de sua biografia em forma de lenda indígena e, ao mesmo tempo, uma evocação de passagens de romances anteriores de Dalcídio Jurandir, como "Três Casas e um Rio" (1958) e "Belém do Grão-Pará" (1960):

Neto de um [rio] de lá de Marajó. (...). Me dou com a biguane de uma sucuriju do lago (...). Ela adotou um curumim, (...) Antônio, (...) meu afilhado. (...) Um dia, (...) bate as asas e (...) se esconde em Belém, na Gentil Bittencourt, 160. (...) casa de uma família toda gorda, gordo o pai, a mãe, gorda a filha (...) uma cria de casa por nome Libânia (...). Uma noite, (...) dois gaviões-reais agarram o fujão (...) e levam ele de volta para o lago, até hoje, xerimbabo da monstra, madrinha dele. Quando vou ao lago (...) me indago (...): O Antônio, (...) como vai, Nhá, Mãe do Lago? (...) Alisando minhas escamas (...). Aqui comigo aprendendo (Jurandir, 1978, p. 128-129).

O comentário da Bi a essa narração de Alfredo verbaliza o trabalho dele como escrevente e escritor: "- O senhor, de tinteiro e pena, não é meu escrivão? (...) senhorzinho Secretário?" (Jurandir, 1978, p. 131). Nestas palavras está contido também um autorretrato do romancista. A estória de Alfredo, em diálogo com a narradora da ribanceira, é um símile de como o escritor Dalcídio Jurandir adapta e integra as narrativas orais da Amazônia em seus romances.

Uma descrição complementar do seu estudo dos saberes locais e do seu método narrativo é fornecida pelo romancista, de modo indireto, quando apresenta o encontro de Alfredo com a contadora D. Sensata, no contexto da festa de São Benedito, onde se misturam missa e dança, santos e pajés:

- Secretário, (...) o que lhe conto é meu invento, um puro imaginar, salpico no acontecido o meu pó de canela. (...) Na batida desses anos, fiz foi aprender da boca alheia, esse-um vem, estória, aquela-uma, maré vem vai, passarinho muda a pena, o que fiz foi tampar neste meu panacu o que só andei foi escutando. / Destampa agora: causos, rescordância, miuçagens, tirando sempre do cesto a figura do Mestre Parijó (Jurandir, 1978, p. 279).

A base dessa arte narrativa é a atenta escuta dos contadores populares que transmitem a cultura ribeirinha por via oral de geração para geração. Nessa transmissão de "causos, rescordâncias, miuçagens", por exemplo, da figura do pajé Mestre Parijó, há também espaço para o "puro imaginar" e para o "invento".

A invenção poética é intimamente ligada à arte da memória, como se vê nesta passagem em que o protagonista, fazendo a sesta na rede, na varanda aberta sobre o rio, escuta vivos e mortos:

\begin{abstract}
Alfredo escuta. Vivos e mortos (...). Comadre Nhá Barbra, esta, lhe abre o baú da família: D. Amélia no chalé, ao espelho, rosto de baunilha e delírio. Pretas de Areinha, passando a ferro a cambraia das brancas, pretos do Araquiçaua apanham goiabas para a calda dos brancos, pretos da Rui Barbosa saem para o torno e o motor da oficina, tio Sebastião cobrindo, com seu negror viajeiro, chãos e rios (...), e aqui, devota do seu pareceiro preto São Benedito, a comadre Nhá Barbra (...), pé no chão, pedindo vela para as suas almas (Jurandir, 1978, p. 259).
\end{abstract}

Ao escutar "vivos e mortos", o presente e o passado, o protagonista Alfredo recorda a história de sua família e mergulha no sentido profundo da festa popular, que adquire uma estrutura de resistência, especialmente a de São Benedito, o protetor dos negros e dos escravos. Dessa forma, o romancista preserva do esquecimento a história cotidiana do povo que é, sobretudo, uma história do trabalho braçal e da escravidão, e que na historiografia oficial costuma ser relegada à margem ${ }^{7}$.

\section{ROMAN-FLEUVE (2) E...}

"Cada romance", observa com razão Benedito Nunes (2006, p. 251) a respeito do ciclo amazônico de Dalcídio

\footnotetext{
7 Esta interpretação do 'memorialismo' de Dalcídio Jurandir como rememoração da história do povo é diferente da de Benedito Nunes (2006, p. 251), que concluiu que no Ciclo do Extremo Norte se dá "a interna harmonia da vívida e vivida lembrança proustiana, que é sempre recordação da infância, se não for sonho de juventude".
}

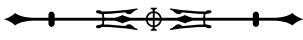


Jurandir, "traz a memória dos que o antecederam". Com efeito, na passagem de "Ribanceira" sobre o "baú da família" do protagonista estão contidas referências a todos os demais romances do ciclo: desde os três livros iniciais, que se desenvolvem na ilha de Marajó; passando por "Belém do Grão-Pará" - um título que projeta para dentro do século XXo tempo da colônia; e passando pelos cinco romances cujo cenário é a periferia da capital paraense - até se chegar novamente ao ponto de partida desse retrospecto: a obra presente, "Ribanceira".

Referências cruzadas de um romance para outro existem, em termos de ambiente geográfico e cultural, desde os dois primeiros: "Chove nos campos de Cachoeira" (1941) e "Marajó" (1947). Apenas não há continuidade de personagens entre esses dois livros, uma vez que, em "Marajó", o autor resolveu experimentar um protagonista diferente: Missunga, o filho rebelde de um latifundiário. A partir de "Três casas e um rio", no entanto, Dalcídio retoma o personagem da obra de estreia, Alfredo, e o mantém como personagem-guia até o último romance. É a partir dessa opção que se configura definitivamente o projeto do ciclo romanesco, em forma de um romanfleuve. Trata-se de uma construção em forma de rede ou labirinto, num nível macro e micronarrativo. Juntamente com isso há um trânsito permanente entre as diferentes zonas demográficas representadas - a fluvial-rural, a urbana e a periférica -, nas quais e entre as quais se movem as dezenas ou centenas de personagens dessas narrativas.

A ideia do ciclo amazônico de Dalcídio Jurandir como roman-fleuve ou "romance-em-forma-de-rio" pode ser representada por meio de uma imagem de pensamento tirada de uma passagem em que uma contadora popular, Dona Sensata, se refere à figura do pajé Mestre Parijó: "Agora [ela] tira do balaio o Mestre Parijó, o adivinhoso, o andejo. $\bigcirc$ Mestre? Pesca sem isca, rema sem remo, come sem comida. (...) Longe anda, longe mergulha, longe escuta, longe adivinha, responde dos longes" (Jurandir, 1978, p. 289).

A descrição de como o lendário feiticeiro se movimenta no espaço fluvial da Amazônia - viajando na casca da Cobra Grande (Jurandir, 1978, p. 120) e estando presente em todos os lugares - talvez possa ser lida também como uma alegoria do modo como o romancista se movimenta nas dez obras do seu ciclo. Com as referências cruzadas, que aumentam à medida que a obra avança, todos os dez romances acabam sendo interligados em um livro único, um grande roman-fleuve, um romance-rio, que se desdobra - como diz o autor na epígrafe de "Marajó", com as palavras do padre Antônio Vieira - "em um confuso e intrincado labirinto de rios (...) com infinitas entradas e saídas". O leitor é incentivado a locomover-se nesse espaço ficcional e fluvial, assim como Mestre Parijó se desloca nas águas do rio Amazonas: a mergulhar longe, nas passagens mais significativas de todos os romances, a escutar longe as correspondências que existem entre eles, e a captar a partir daí os diversos sentidos da obra, com uma sensibilidade adivinhatória, como requer a arte da hermenêutica. Parece que aqui um mito da Amazônia oferece para a teoria literária uma descrição metanarrativa e um modelo concreto para explicar a composição da obra.

\section{...DICTIO-NARIUM (2)}

O gênero do roman-fleuve serve a Dalcídio Jurandir como suporte para o seu projeto de organizar um dictio-narium dos habitantes da Amazônia. Um estímulo importante para esta pesquisa foi a observação de Benedito Nunes (2006, p. 248) de que a narrativa do romancista "sempre primou (...) pelo relevo dado à fala dos personagens". No entanto, o objetivo aqui não consiste em apenas corroborar e ilustrar as opiniões do crítico, mas em aproveitar o diálogo com ele para procurar detectar quais são os principais desafios para investigações futuras sobre o Ciclo do Extremo Norte.

Com respeito ao projeto dalcidiano de um dictionarium, ou seja, de uma coletânea das dicções e dos falares do povo, é preciso distinguir entre três tipos de enfoque desses fenômenos pela recepção: o estudo linguístico, a análise e interpretação literária e o que se pode chamar 'a função emancipatória das falas'.

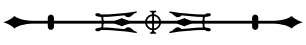


Entre os estudos linguísticos, o trabalho mais significativo foi realizado por Rosa Assis, que é também a organizadora de várias reedições dos romances. O seu "Vocabulário popular em Dalcídio Jurandir" (Assis, 1992), o glossário "Evém chuva..." (Assis e Cerqueira, 2009) e o estudo "A fala 'caboca' em 'Passagem dos Inocentes'” (Assis, 2002) constituem referências fundamentais e obrigatórias para quem deseja se inteirar da linguagem e da cultura retratadas por Dalcídio Jurandir. Essas pesquisas do 'material' linguístico e da 'gramática' dalcidiana necessitam, no entanto, dos estudos estilísticos e literários como complemento para se compreender a função "da fala dos personagens na fabulação da narrativa e no seu desenvolvimento romanesco" (Nunes, 2006, p. 248).

Inversamente, o desafio para os estudiosos que se propõem oferecer uma visão de conjunto da obra de Dalcídio - as monografias em forma de livro, como as de Olinda Batista Assmar (2003) e de Marli Tereza Furtado (2010), ou os ensaios como os de Temístocles Linhares (1987), Pedro Maligo (1992), Gunter Pressler (2010) e Benedito Nunes (2006) - consiste em saber reconhecer a importância estratégica das dicções e das falas no projeto do escritor. É de se notar que somente no estudo de Benedito Nunes esse aspecto é prioritário.

Um desafio correlato para os estudiosos da literatura é a questão da qualidade da obra de Dalcídio, sobretudo quando se trata de avaliar o seu estilo 'documental'. Um excesso de zelo estético e a vontade de atribuir à obra a todo custo um valor universal podem eclipsar a compreensão de algo que é tão importante em Dalcídio quanto a sua 'obra': o seu 'projeto'. O que está em jogo pode ser ilustrado com o caso do drama barroco alemão, magistralmente analisado por Walter Benjamin (1984). Em termos de qualidade estética, aquelas produções situamse muito aquém das obras coetâneas de Calderón ou de Shakespeare. No entanto, como Benjamin demonstrou, o drama barroco alemão, analisado como "oficina literária", como expressão de uma "vontade artística" (Kunstwollen) e como "projeto político", proporciona um conhecimento da História que nada fica devendo em qualidade em comparação com aquelas obras-primas.

Resulta daí como tarefa da crítica em relação ao ciclo amazônico de Dalcídio Jurandir: revelar as qualidades de sua representação da cultura amazônica enquanto 'projeto'; inclusive de reverter a constatação de certas insuficiências literárias e estéticas como indicativos de problemas que estão em aberto, mesmo porque os problemas dos quais tratam as 'obras' continuam sem solução no espaço fora delas, nos movimentos do tempo histórico e social.

É nesse sentido que se propõe aqui - como complemento necessário dos estudos linguísticos e literários, e à guisa de conclusão deste estudo, um enfoque da função emancipatória das falas nos romances de Dalcídio Jurandir. Não se trata de saber apenas quais são os componentes linguísticos das falas selecionadas, nem somente de discernir se uma determinada fala faz parte do estilo indireto livre do narrador ou do monólogo interior de um personagem. E mesmo quando se consegue esclarecer a função de uma fala para o significado de um romance inteiro, ainda se pode ir mais longe: trata-se de revelar em que medida as falas dos personagens os qualificam como sujeitos da História. Eis a questão que transcende o âmbito da 'obra literária' e das discussões sobre a qualidade 'estética' como finalidade última: o dictio-narium contido no roman-fleuve de Dalcídio resulta de uma seleção de falas que o romancista captou no ambiente social em sua volta, na boca do povo, que ele retrabalhou na sua 'oficina literária', e que ele devolveu, nessa forma retrabalhada, para o espaço público como um acervo permanente de aprendizagem da emancipação social.

\section{À GUISA DE RESUMO: DEZ FALAS, UMA DE CADA ROMANCE}

A ideia-guia deste estudo é que as falas mais significativas dos personagens de Dalcídio Jurandir não são apenas amostras linguísticas do falar amazônico, nem tão somente componentes de uma obra literária, mas que elas representam a contribuição da língua e da literatura para

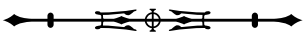


a história social e política com falas que têm uma função emancipatória. Para resumir e ilustrar essa ideia, esboça-se aqui um tableau com dez falas significativas, selecionadas em cada um dos dez romances do ciclo. A ordem em que se apresenta essa amostra de falas não é a da cronologia das obras, mas a da memória associativa do pesquisador.

O ponto de partida é a cena na Praça da República, em "Passagem dos Inocentes" (1963), que mostra o povo protestando contra o descaso das autoridades diante do surto epidêmico que causa a morte de muitas crianças. Como fala expressiva, selecionou-se aqui a de uma das mães, em resposta à repressão do protesto pela cavalaria: "- Os doutores (...) conferenciam. Vão curar a doença mandando carregar as armas contra as mães?" (Jurandir, 1984, p. 213).

As pessoas do povo aparecem como sujeitos da história não apenas em 'grandes' cenas coletivas e políticas, mas também em micro cenas, no limite com apenas dois atores. Um exemplo é uma cena relembrada por Dona Abigail, em "Primeira Manhã” (1967). Ela narra um confronto no confessionário da igreja entre ela, que estava para se tornar moça, e o padre, que procurou aproximar-se dela com segundas intenções. $\bigcirc$ padre foi abrir a janelinha do confessionário e lhe cochichou umas palavras das quais ela "nunca mais [se] esquec[eu]": "entreaberto botão, entrefechada rosa...". Diante desse insinuante avanço do eclesiástico, a moça, contudo, não se dá por achada e responde à altura. Ela "[se] bot[a] de pé, enfi[a] a cabeça pela janelita, f[az] uma língua deste tamanho pro padre" e lhe devolve a fala: "entreaberto é a mãe, reverendo, cuche!” (Jurandir, 2009, p. 126-127). Este caso é exemplar para a obra inteira de Dalcídio Jurandir e o seu projeto literário e político. Ele mostra como uma pessoa do povo, não letrada, consegue enfrentar de igual para igual um representante da cultura dominante, revertendo contra ele a arma principal da dominação, que é o poder da palavra.
Um outro exemplo marcante é a resposta de uma cabocla, em "Marajó" (1947), quando os trabalhadores são expulsos da plantação "Felicidade", um pseudoprojeto de reforma social, idealizado por Missunga, o filho (aparentemente) rebelde de um latifundiário opressor: "Uma mulher havia arrancado a tabuleta: FELICIDADE para utilizá-la como remo" (Jurandir, 2008, p. 221). 0 modo como a cabocla refuncionaliza a tabuleta mentirosa é exemplar sob vários aspectos: 1) com essa resposta, ela atinge plenamente o alvo, pois para o leviano idealizador do projeto esse gesto é "pior do que vaia": "aquilo humilhava-o e o expulsava também"; ou seja, o dominador letrado sente que ele é derrotado com a sua própria arma verbal por uma iletrada que ele supunha ser inteiramente dominada; 2) o gesto da cabocla é um expressivo exemplo de uma 'história a contrapelo', no sentido de Walter Benjamin; 3) a inclusão, por parte do romancista, de falas que mostram os caboclos no papel de sujeitos da história, representou uma iniciativa pioneira no campo de literatura, à qual vêm se somar movimentos políticos no presente, como os dos quilombolas na ilha de Marajó (Acevedo Marin, 2008).

A amostra seguinte é também de um romance que se passa no Marajó, em Cachoeira do Arari. Em "Três casas e um rio" (1958), Lucíola Saraiva, uma cabocla solteirona que queria assumir o papel da mãe de Alfredo, é pedida em casamento pelo filho de latifundiário, Edmundo Menezes. Este acaba de voltar de uma longa estadia de estudos na Inglaterra, sonhando com projetos de reforma social - o que contrasta com a violência e os crimes praticados por seus familiares contra os caboclos. Por que Edmundo pedira Lucíola em casamento, pergunta-se toda a comunidade, inclusive a noiva. Na hora do casamento, que parece a ela "um inquérito policial, um júri, em que ela e Edmundo fossem os réus", o noivo "apress[a]-se a responder, como se confessasse: - Sim". A noiva, por seu lado, responde, seca e breve: "Não" (Jurandir, 1994, p. 369).

\footnotetext{
8 Ver, ainda, os documentos apresentados e comentados por Rosa Acevedo Marin, em "Quilombolas da ilha de Marajó" (fascículo 7 do Projeto Nova Cartografia Social da Amazônia, coordenado por Alfredo Wagner Berno de Almeida, Manaus); e na Ata da Audiência Pública sobre a ocupação das terras e águas do município de Salvaterra, lavrada em 10 maio 2005 (fotocópia cedida pela pesquisadora).
}

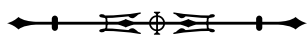


Do sangue dos Menezes é também a esposa do fazendeiro coronel Boaventura, Dona Jovita, que proíbe a sua filha Luciana de frequentar o Ginásio, uma história que começa em "Primeira Manhã" e termina em "Os habitantes" (1976). Luciana, que nasceu de uma aventura de D. Jovita com um vaqueiro, provoca em sua irmã Graziela, que é filha legítima do casal Boaventura, um profundo ressentimento. O monólogo interior em que Graziela manifesta toda a sua inveja e o seu rancor contra Luciana, lê-se como uma alegoria do que sentem os privilegiados diante da perspectiva de que um dia os caboclos possam ter pleno acesso a todas as oportunidades da educação:

Mas debaixo da surra [dada por d. Jovita] saltava a mesma menina, aquela, de repente sabendo ler, escrever e contar, respondia tudo na bucha, desembaraço, que só visto oh, memória! Num instante fez colegas, mestra, gente grande, vissem nela a de mais cabeça. (...) E a menina, ciente do seu dom, então que tomou conta, se fez farsola, tome altura, tome altura, juntando cada astúcia, a arteirice em tudo, na pontinha da língua o recitativo e o substantivo, pinta a saracura, quando se vê lá está a demônia já tirando os nove na pedra (Jurandir, 1976a, p. 119).

A inveja de Graziela é do tamanho do pesadelo da classe dominante de que um dia ela possa ser superada pelo saber dos de baixo.

O acesso dos pobres à educação é um tema fundamental em todos os romances de Dalcídio Jurandir, do primeiro até o último. Em "Chove nos campos de Cachoeira" (1941), o protagonista Alfredo, de uns dez anos, implora à mãe: “- Mamãe, me mande para Belém. Eu morro aqui, mamãe. Cresço aqui e não estudo. Quero estudar, quero sair daqui" (Jurandir, 1998, p. 299).

O sonho de Alfredo demora para se realizar, mas, diferentemente do caso de Luciana, se realiza. No quarto romance, "Belém do Grão-Pará" (1960), ele desembarca finalmente em Belém, onde mora na casa da família Alcântara e estuda no Grupo Escolar Barão de Rio Branco. A escola é, para Alfredo, um meio de formação e ao mesmo tempo de ascensão social. Ele incorpora essa sensação de status à sua postura, especialmente em relação à empregada Libânia: "Tinha de estar, como estudante, um degrau acima da cabocla", a qual, "de pé no chão, era da serventia dos Alcântaras" (Jurandir, 2004, p. 204). A empregada, no entanto, sabe lhe pôr limites, quando é preciso, como na cena em que ele se mostra todo orgulhoso de constar do quadro de honra da escola:

- Quadro de Honra não dá banana, viu, seu
aquelezinho? Aprenda aqui com esta professora.
A mão, áspera e firme, no pulso de Alfredo (...):
- Mão de roceira desde gita, aquele-menino.
Carreguei puçá de mandioca, virei farinha no forno,
remei de me doer a mão e a bunda, assoalhei
barraca, embarriei parede, sou curada de cobra, pajé
me defumou, tenho oração (Jurandir, 2004, p. 177).

O estudante aprende, então, que, além do Grupo Escolar, com suas professoras "cheirosas" e de "linguagem própria, exclusiva”, existe na vida ainda um outro tipo de escola, tão importante quanto o ensino oficial.

O confronto entre os saberes formais do ginásio e os saberes significativos da escola da rua marca a experiência de Alfredo, então com dezesseis anos, em "Primeira Manhã" (1967) e "Ponte do Galo" (1971). Entediado pelas aulas, o protagonista sente-se atraído pelos mistérios da rua, em que há também um componente erótico. $\bigcirc$ contraponto à mitificação dos saberes da rua é uma cena de "Ponte do Galo", em que a mãe de Alfredo lhe conta os abusos de poder e as crueldades cometidas na vila do interior pelo recém-nomeado prefeito de polícia, que é Edgar Menezes, um bandido e assassino. A mãe conclui o seu relato com este conselho: "Tua desforra é estudar, meu filho. Que os brancos te invejem, que os brancos passem por debaixo do teu pé, (...) tudo isso alivia o coração daqueles que sofreram na mão deles, meu filho" (Jurandir, 1971, p. 119)

Nos dois romances finais, as falas proferidas pelos pobres não são muito animadoras. Em "Chão dos Lobos" (1976), Alfredo reencontra seu Almerindo, que ele conheceu em "Passagem dos Inocentes", numa festa que

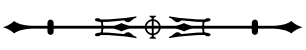


ele organizou em Santana, no Marajó, como presidente da irmandade de São Sebastião. A narração de seu Almerindo é o resumo de uma vida de migrante:

Ah, Santana! Acabou-se. (...) Os brancos me pedem o barracão de volta, que de lei é deles, então, no relento sem no que me agarrar, atravesso para a cidade com a família nas costas. A irmandade finou-se (...). Pra onde vou? Onde o agasalho? (...) Remexo esta cidade. Já peguei um lugar de vigia numa usina, começo amanhã. Assim faço parte desta população, finco na baixa deste subúrbio a mea raiz marajoara. Começa sempre, sim, há quantos anos, começando sempre, faz desfaz... (...) A sorte não maldigo. (...) $\bigcirc$ folgo não perdi. (...) Ainda sei rir, sim, entro nessa cidade feito um de primeira viagem (Jurandir, 1976b, p. 187-188).

É a coragem e a moral de quem não se resigna e quer sobreviver. Disso faz parte também a disposição de seu Almerindo de logo mais reunir com a sua filha uma nova irmandade e de organizar um cordão.

Essa coragem já não existe nos "desviventes" do último romance, "Ribanceira" (1978). Para os Seruaias, falta a comida básica para sobreviver. Nessa situação, sem perspectiva, a Bernarda, "com seu goelão asselvajado", solta o seu grito de desespero: “- (...) tacar bala (...) em toda essa cambada de desvivente que é nós aqui neste chiqueiro excomungado e me jogar aí nesse Amazona, égua-te!" (Jurandir, 1978, p. 320).

Assim como a Ribanceira é a alegoria de uma cidade que recaiu no estado natural, o grito "asselvajado" daquela mulher é a recaída do ser humano no estado dos animais, além de um desejo de suicídio coletivo. Esse grito da "desvivente", nas páginas finais do ciclo de Dalcídio, faz eco ao grito do cego do Arapinã, nas páginas iniciais do segundo romance, "Marajó", que lembra "a voz dos homens primitivos gritando o seu medo e a sua dor" (Jurandir, 2008, p. 33).

Com esta seleção final de falas, extraídas de todos os dez romances do ciclo de Dalcídio Jurandir, procurouse apresentar algo a mais do que uma coletânea de falares regionais ou de citações literárias: uma constelação de fragmentos que expressam a história social da Amazônia e nos quais possam ser reconhecidos não apenas personagens de ficção, mas sujeitos da História real. Para resumir o roman-fleuve e o projeto do dictio-narium caboclo com uma imagem, pode-se recorrer novamente à epígrafe de "Marajó", desta vez ao início da citação do padre Vieira: é como se o romancista da ilha de Marajó, de Belém e do vasto interior fluvial tivesse captado, trabalhado e recolocado todas essas falas "na grande boca do rio das Amazonas".

\section{AGRADECIMENTOS}

A conferência da qual esse ensaio se originou teve como título "A Amazônia entre o mítico e o científico: Dalcídio Jurandir à luz de Alexander von Humboldt" e foi apresentada em 27 de outubro de 2010, na Universidade do Estado do Pará, em Belém, no âmbito do projeto "Amazônias: Paisagens, Narrativas, Sentidos", organizado por Josebel Fares. Agradeço a Josebel Fares, Antonio Candido, Agenor Sarraf e Renan Freitas Pinto, pelo diálogo durante a elaboração deste estudo. Ao Conselho Nacional de Desenvolvimento Científico e Tecnológico (CNPq), pela bolsa de pesquisa.

\section{REFERÊNCIAS}

ANDRADE, Mário de. Macunaíma. Ed. crítica org. por Telê Porto Ancona Lopez. Rio de Janeiro: Livros Técnicos e Científicos; São Paulo: Secretaria da Cultura, Ciência e Tecnologia, 1978.

ASSIS, Rosa. A fala 'caboca' em Passagem dos Inocentes. Belém: UNAMA, 2002.

ASSIS, Rosa. O vocabulário popular em Dalcídio Jurandir. Belém: EDUFPA, 1992.

ASSIS Rosa; CERQUEIRA, Ana. Evém chuva...: um glossário de Dalcídio Jurandir. 2. ed. Belém: Ed. Amazônia, 2009.

ASSMAR, Olinda Batista. Dalcídio Jurandir: um olhar sobre a Amazônia. Rio de Janeiro: Galo Branco, 2003.

BARTHES, Roland. Essais critiques. Paris: Seuil, 1964.

BENJAMIN, Walter. Origem do drama barroco alemão. São Paulo: Brasiliense, 1984.

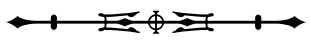


BOLLE, Willi. Halbvergessen oder verdrängt? Dalcídio Jurandirs Romanzyklus über Amazonien. Martius-Staden-Jahrbuch, São Paulo, n. 58, p. 113-132, 2011.

BOSI, Alfredo. História concisa da literatura brasileira. 46. ed. São Paulo: Cultrix, 2006.

CANDIDO, Antonio. Formação da Literatura Brasileira. 6. ed. Belo Horizonte: Itatiaia, 1981. 2 v.

FURTADO, Marli Tereza. Universo derruído e corrosão do herói em Dalcídio Jurandir. Campinas: Mercado de Letras, 2010.

GRIMM, Jacob. Vorrede zum Deutschen Wörterbuch. In: GRIMM, Jacob. Kleinere Schriften. Hildesheim: Georg Olms, 1966 [1854]. v. 8 , p. 302-380.

HUMBOLDT, Alexander von. Vues des Cordillères et Monuments des Peuples Indigènes de l'Amérique. Ed. org. por Charles Minguet e Amos Segala. Nanterre: Editorial Erasme, 1989 (1. ed., 1810-1813).

HUMBOLDT, Alexander von. Relation historique du Voyage aux Régions Équinoxiales du Nouveau Continent. Editado e organizado por Hanno Beck. Stuttgart: Brockhaus, 1970. 3 v. (1. ed., 1814-1825).

JURANDIR, Dalcídio. Primeira Manhã. 2. ed. Belém: EDUEPA, 2009 [1967].

JURANDIR, Dalcídio. Marajó. 4. ed. Belém: EDUFPA; Rio de Janeiro: Casa de Rui Barbosa, 2008 [1947].

JURANDIR, Dalcídio. Belém do Grão-Pará. 2. ed. Belém: EDUFPA; Rio de Janeiro: Casa de Rui Barbosa, 2004 [1960].

JURANDIR, Dalcídio. Chove nos Campos de Cachoeira. 6. ed. Belém: UNAMA, 1998 [1941].

JURANDIR, Dalcídio. Três casas e um rio. 3. ed. Belém: CEJUP, 1994 [1958].
JURANDIR, Dalcídio. Passagem dos Inocentes. 2. ed. Belém: Falângola, 1984 [1963].

JURANDIR, Dalcídio. Ribanceira. Rio de Janeiro: Record, 1978.

JURANDIR, Dalcídio. Os habitantes. Rio de Janeiro: Artenova, 1976a.

JURANDIR, Dalcídio. Chão dos Lobos. Rio de Janeiro: Record, 1976b.

JURANDIR, Dalcídio. Ponte do Galo. São Paulo: Martins; Rio de Janeiro: INL, 1971.

LINHARES, Temístocles. Do extremo Norte ao extremo Sul. In: LINHARES, Temístocles. História crítica do romance brasileiro, 1728-1981. Belo Horizonte: Itatiaia; São Paulo: EDUSP, 1987. v. 2. p. 401-441.

MALIGO, Pedro. Ruínas idílicas: a realidade amazônica em Dalcídio Jurandir. Revista USP, São Paulo, n. 13, p. 48-57, 1992.

MARIN, Rosa Elizabeth Acevedo. Quilombolas na Ilha de Marajó: território e organização política. In: LIMA, M. D.; PANTOJA, V. (Orgs.). Marajó: culturas e paisagens. Belém: $2^{\mathrm{a}} \mathrm{SR} / \mathrm{IPHAN}$, 2008. p. 163-187.

NUNES, Benedito. Dalcídio Jurandir: as oscilações de um ciclo romanesco. In: NUNES, Benedito; PEREIRA, Ruy; PEREIRA, Soraia Reolon (Orgs.). Dalcídio Jurandir: romancista da Amazônia. Belém: SECULT; Rio de Janeiro: Fundação Casa de Rui Barbosa, 2006. p. 245-251.

PRESSLER, Gunter Karl. O maior romancista da Amazônia Dalcídio Jurandir - e o mundo do arquipélago de Marajó. In: BOLLE, Willi; CASTRO, Edna; VEJMELKA, Marcel (Orgs.). Amazônia - região universal e teatro do mundo. São Paulo: Globo, 2010. p. 235-259.

WAGLEY, Charles. Uma comunidade amazônica. 3. ed. Belo Horizonte: Itatiaia; São Paulo: EDUSP, 1988 [1953].

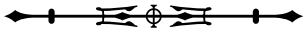

